\title{
Network Analysis and Comprehensive Evaluation of Geological Hazard Monitoring based on Satellite Data
}

\author{
LI Yi-qiu ${ }^{1,2,3}$, YANG Guang-bin ${ }^{3 *}$, CHEN Pan-pan ${ }^{1}, \mathrm{HU}$ Li-li ${ }^{1}$ and DENG Ou ${ }^{1,2}$ \\ ${ }^{1}$ Ecological Security and Protection Key Laboratory of Sichuan Province, \\ Mianyang Normal University, Mianyang, China, 621000 \\ ${ }^{2}$ Institute of Geographical Sciences and Natural Resources Research, CAS, \\ Beijing, China, 100101 \\ ${ }^{3}$ Department of Geography and Environment Sciences, Guizhou Normal \\ University, Guiyang, China, 550001 \\ ${ }^{1}$ yqiu.li@163.com
}

\begin{abstract}
5.12 Wenchuan earthquakes triggered very serious secondary geological disasters in Pengzhou segment of Longmen Shan fault zone. Using the high-resolution satellite of post-earthquake, French Pleiades satellite, remote sensing image interpretation data, combined with the geological disaster point field survey data of Pengzhou, we selected the hazard inducing environmental factors, disaster-causing factors, hazard bearing bodies factors and made a study of comprehensive evaluation and zoning to the geological disasters risk in Pewngzhou of Longmen Shan fault zone by GIS spatial analysis and AHP. The results showed that: High risk areas account for $16.44 \%$ of Pengzhou, and mainly distributed in northern mountainous; moderate risk areas account for $36.24 \%$ of Pengzhou, and mainly distributed in the northern mountainous and central hilly areas; low risk areas account for $36.15 \%$ of Pengzhou, and mainly distributed in the central hilly areas; Relatively safe areas account for 36.15\% of Pengzhou, and mainly distributed in the eastern plain area. It is of great significance for the local economic and social development and people's lives and property safety to establish and improve the geological disaster monitoring network, methods and prevention measures basing on the zoning status of geological disasters risk areas.
\end{abstract}

Keywords: Longmenshan; Geological disasters; Risk assessment; Pengzhou

\section{Introduction}

Geological hazard is disaster events that formed by the nature or human's geological process such as mountain collapse, landslide, debris flow, ground collapse, which causes a loss to human life and material wealth, or serious damage to the ecological environment [1]. Geological disaster risk assessment is a comprehensive analysis on the historical point disaster situation, natural conditions, geological conditions, human activities situation of a region or a potential point of geological hazard, to determine the probability of disaster event which threatens human lives and property safety [2]. Geological hazard assessment can be traced back to 1977, Japanese scholar put forward the "The judgment of risk of landslides" in statistical analysis based on the background elements [3]. After decades of development, the risk judgment and evaluation methods from early expert field survey combined with aerial photographs, has gradually developed into comprehensive analysis and model simulation, combined with computer technology, mathematical models algorithms, Earth System Science, GIS (Geographic Information System), remote sensing

${ }^{*}$ Corresponding Author 
and technology [4-6]. At present, the main research methods of geological disaster risk assessment includes Analytic Hierarchy Process [7-8], expert marking model [3-8], Logistic model [8-9], Artificial neural network model [10-11], Information Value Model[12-13] and 3S integrated techniques [14-16] etc., Geological disasters in China occurred frequently in recent years, geological hazard risk assessment has become an important work, large numbers of research results has been promoting the progress of geological disaster risk assessment.

\section{Study Area}

May 12, 2008, Richter 8.0 earthquake took place in Wenchuan County, Sichuan Province, the scale, the density degree and the complexity of secondary geological disasters triggered by 5.12 earthquake such as the collapse, landslide and debris flow are unparalleled, and had caused more serious harm than the earthquake itself [17]. The main fault of Longmenshan Fault zone and its south branch crosses and controls the north areas of Pengzhou. Both two faults had activity sighs in the 5.12 earthquake, many villages and towns of northern Pengzhou located in the fault zone [18-20]. As the very severely affected counties in the 5.12 earthquake, geological disasters have hampered the Pengzhou's local economic and social development badly, posing a serious threat to people's lives and property safety. This article took Pengzhou section of Longmen Shan fault zone as the research object, constructed an index system from three aspects :the hazards inducing environmental factors、 disaster-causing factors、 hazard bearing bodies factors, by means of $3 \mathrm{~S}$ technology powerful spatial data analysis and spatial modeling capability, and completed geological hazard risk assessment and distribution map of Pengzhou section of Longmen Shan fault zone, thereby providing data support for prevention, forecasting and early warning of geological disasters for Pengzhou, and providing scientific reference for the government in Pengzhou to draw up disaster prevention and mitigation policies.

\section{Materials and Methods}

\subsection{Materials}

The main data sources of the article include basic geographic data of Pengzhou City and it's surrounding area (administrative boundaries, river systems, road traffic data, etc.,), and the land-use type data and residential areas distribution data obtained by Pleiades image remote sensing interpretation together with $30 \mathrm{~m} * 30 \mathrm{~m}$ DEM; and statistical data, geological hazard point data obtained from remote sensing interpretation and spot survey, precipitation observation data. fault zone, aftershocks and seismic intensity distribution data were obtained by digital measures, the basic steps including co registrating image, editing the vector diagram and entering space data into database.

\subsection{Methods}

(1) The establishment of evaluation index system and evaluation standard

It is very difficult to establish the evaluation index system, the evaluation index system of project evaluation in each field has no universal standard, it often relies on the experience of experts in the field and makes trade-offs according to the actual situation of the project. The article choose hazard inducing environmental factor, disaster-causing factor, hazard bearing bodies factor as three evaluation index and confirm the grading and score of each evaluation index of geological disasters risk according to the relevant documents, expert experience, geometric interval classification in ARCGIS and region actual situation (Table 1). 
Table 1. Factors and its Grading Value

\begin{tabular}{|c|c|c|c|c|}
\hline \multirow{2}{*}{$\begin{array}{l}\text { Value } \\
\text { Evaluation index }\end{array}$} & \multicolumn{4}{|c|}{ Classification and Assignment } \\
\hline & 1 & 2 & 3 & 4 \\
\hline $\begin{array}{c}\text { Hazards inducing } \\
\text { environment sensitivity }\end{array}$ & $\begin{array}{l}\text { Insensitiv } \\
\mathrm{e}\end{array}$ & $\begin{array}{c}\text { Low } \\
\text { sensitive }\end{array}$ & $\begin{array}{l}\text { Moderate } \\
\text { sensitive }\end{array}$ & $\begin{array}{c}\text { High } \\
\text { sensitive }\end{array}$ \\
\hline $\begin{array}{l}\text { Distance from the fault } \\
\text { zone }(\mathrm{m})\end{array}$ & $>20000$ & $\begin{array}{l}10000- \\
20000\end{array}$ & 5000-10000 & $<5000$ \\
\hline Sea-level elevation (m & $>3000$ & $650-1000$ & $2000-3000$ & $1000-2000$ \\
\hline $\begin{array}{l}\text { Amplitude of } \\
\text { landforms (m) }\end{array}$ & $<50$ & $50-100$ & $100-200$ & $>200$ \\
\hline $\begin{array}{l}\text { Hydrological condition } \\
\text { (Distance from the } \\
\text { river }(\mathrm{m}) \text { ) }\end{array}$ & $>1000$ & $500-1000$ & $200-500$ & $<200$ \\
\hline $\begin{array}{l}\text { Disaster-causing } \\
\text { factors risk }\end{array}$ & $\begin{array}{l}\text { Relatively } \\
\text { safe }\end{array}$ & Low risk & Moderate risk & High risk \\
\hline $\begin{array}{l}\text { Seismic intensity and } \\
\text { distribution }\end{array}$ & & $<$ VII & VIII-IX & $\mathrm{X}-\mathrm{XI}$ \\
\hline $\begin{array}{l}\text { Level and distribution } \\
\text { of aftershocks }\end{array}$ & $\begin{array}{l}\text { Level } 4 \text { or } \\
\quad \text { less }\end{array}$ & 4-5 level & 5-6 level & $\begin{array}{l}\text { Level } 6 \text { or } \\
\text { above }\end{array}$ \\
\hline $\begin{array}{l}\text { Historical disaster scale } \\
\text { and distribution }\end{array}$ & & Small & Medium & Large \\
\hline $\begin{array}{l}\text { Multi-year average } \\
\text { precipitation }\end{array}$ & $\begin{array}{l}<1000 \mathrm{~m} \\
\mathrm{~m}\end{array}$ & $\begin{array}{c}1000- \\
1200 \mathrm{~mm}\end{array}$ & $\begin{array}{c}1200- \\
1400 \mathrm{~mm}\end{array}$ & $>1400 \mathrm{~mm}$ \\
\hline $\begin{array}{l}\text { Hazard bearing bodies } \\
\text { vulnerability }\end{array}$ & $\begin{array}{l}\text { Relatively } \\
\text { safe }\end{array}$ & $\begin{array}{c}\text { Low } \\
\text { vulnerability }\end{array}$ & $\begin{array}{c}\text { Moderate } \\
\text { vulnerability }\end{array}$ & $\begin{array}{c}\text { High } \\
\text { vulnerability }\end{array}$ \\
\hline $\begin{array}{l}\text { Land cover/land-use } \\
\text { types }\end{array}$ & & $\begin{array}{l}\text { Coniferous } \\
\text { forest mixed } \\
\text { forest、 } \\
\text { broadleaf } \\
\text { forest }\end{array}$ & $\begin{array}{l}\text { Construction } \\
\text { land、 } \\
\text { cultivated } \\
\text { Land、waters }\end{array}$ & $\begin{array}{c}\text { Shrub、 } \\
\text { grassland } \\
\text { bare and } \\
\text { wasteland }\end{array}$ \\
\hline $\begin{array}{l}\text { Distance from } \\
\text { residential/area }(\mathrm{m})\end{array}$ & $<500$ & $500-2000$ & $2000-8000$ & $>8000$ \\
\hline $\begin{array}{l}\text { Distance from road } \\
\text { traffic }(\mathrm{m})\end{array}$ & $<600$ & $600-2500$ & $2500-9500$ & $>9500$ \\
\hline
\end{tabular}

(2) Constructing the spatial model and zoning

Calculating the evaluation index weights by AHP(analytic hierarchy process), the comprehensive risk score space distribution data were obtained by GIS spatial modeling arithmetic, and the geological disaster risk zoning is carried out by ARCGIS geometric interval classification [21]. The principle of creating geometric interval classification scheme is to minimize each class element numerical sum of squares, ensure the scope and the value of each class have roughly the same value, and the change of the interval between two classes is very consistent.

\section{Data Processing and Results}

\subsection{Hazards Inducing Environment Sensitivity and its Grading}

The sensitivity of geological disasters of hazard inducing environment is a quantitative index to measure region hazard inducing environment, which plays a decisive role on geological disasters system's complexity and the situation of a disaster, and reflects the 
degree of difficulty or the possibility of appearing geological disasters when the regional ecosystems face the interference [22]. The article took the fault distance, sea-level elevation, amplitude of landforms and hydrological conditions (according to the distance from the rivers) as the evaluation index of geological disasters sensitivity of hazards inducing environment.

Longmen mountain Pengzhou fault zone distribution map was obtained by scandigitizing; the sea-level elevation data and amplitude of landforms data were obtained by the $30 \mathrm{~m} * 30 \mathrm{~m}$ DEM attribute data extraction, surface analysis and spatial neighborhood information; river system data were derived from the 1: 50000 basic geographic data map. The Longmen mountain Pengzhou hazard inducing environment's sensitivity grading distribution map (Figure 1) according to the classification standards of indexes shown in Table 1.
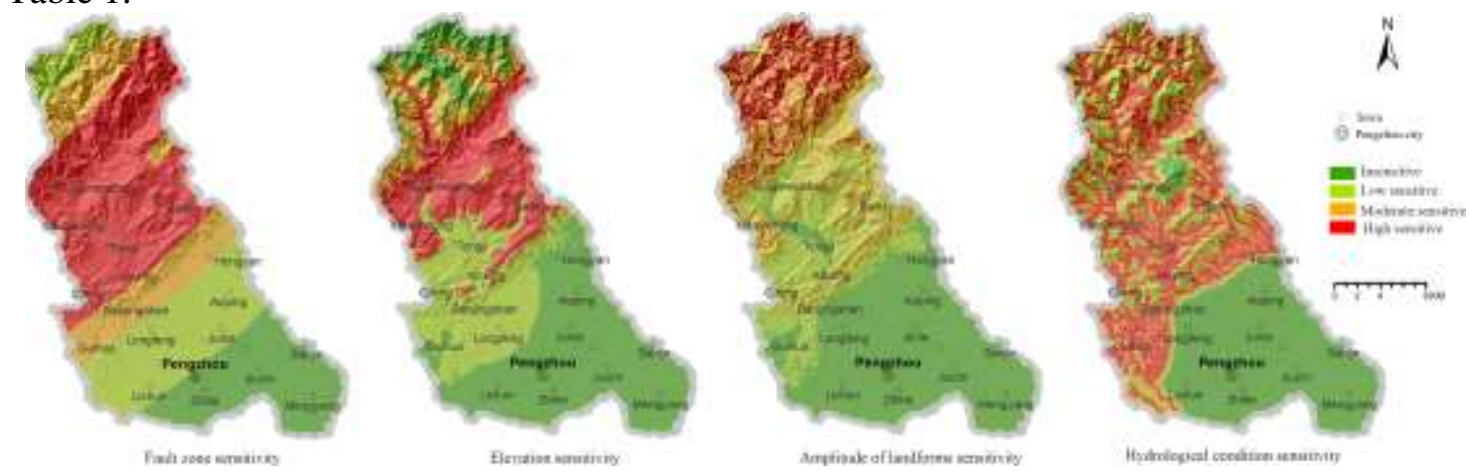

\section{Figure 1. Hazards Inducing Environment Sensitivity and its Grading Distribution Map}

\subsection{The Disaster-Causing Factors Risk and its Grading}

The disaster-causing factors are mutagenic factors of hazard inducing environment [22] which may cause problems such as property damage, casualties, resources and environment destruction and social system chaos. The article selects the 5.12 earthquake intensity, and its aftershocks grading, historical disaster's scale and distribution, and annual average precipitation distribution as the indexes of the disaster-causing factors risk assessment.

The intensity and distribution of 5.12 earthquake and aftershocks' grading and distribution in Longmen mountain Pengzhou section were obtained by scan-digitizing, historical disaster's scale and distribution were obtained from related statistical data spot investigation and Pleiades remote sensing image interpretation, the annual average precipitation distribution was obtained by ARCGIS Kriging differential method according to the weather observation data of study area and its surrounding areas. According to the classification standards of indexes show in Table 1, (Figure 2), the Longmenshan Pengzhou segment's disaster-causing factors risk grading distribution is mapped as below.
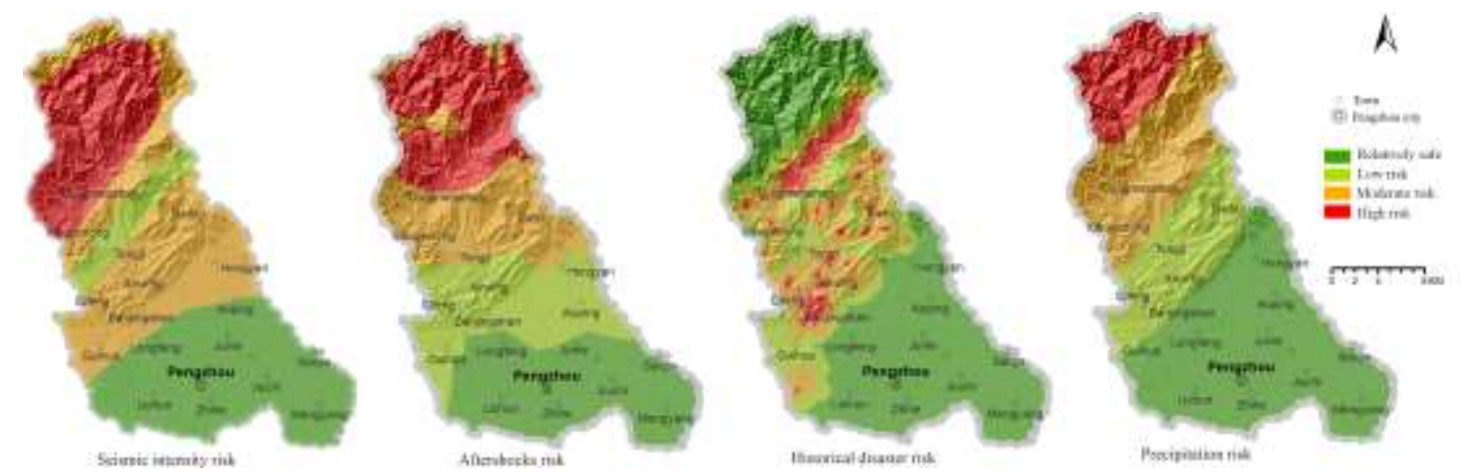

Figure 2. Disaster-Causing Factors Risk and its Grading Distribution Map 


\subsection{Hazard Bearing Bodies Vulnerability and its Grading}

The vulnerability of hazard bearing bodies is the root of disaster formation, it affects hazard bearing bodies' ability to resist natural disasters and resuming after disaster. The formation of the disaster is the results that the hazard bearing bodies can't adapt or adjust to the change [23]. The article selects the land cover/land-use type, residential area distribution, traffic distribution as the vulnerability assessment indexes of hazard bearing bodies.

The land cover/land-use type, residential areas distribution data in Longmen mountain Pengzhou section were obtained by Pleiades remote sensing image interpretation, traffic distribution was obtained from 1:50000 basic geographic data map, and updated according Pleiades high remote sensing image. According to the classification standards of indexes shown in Table 1, (Figure 3), the hazard bearing bodies vulnerability grading distribution of Longmenshan Pengzhou section is mapped as below.
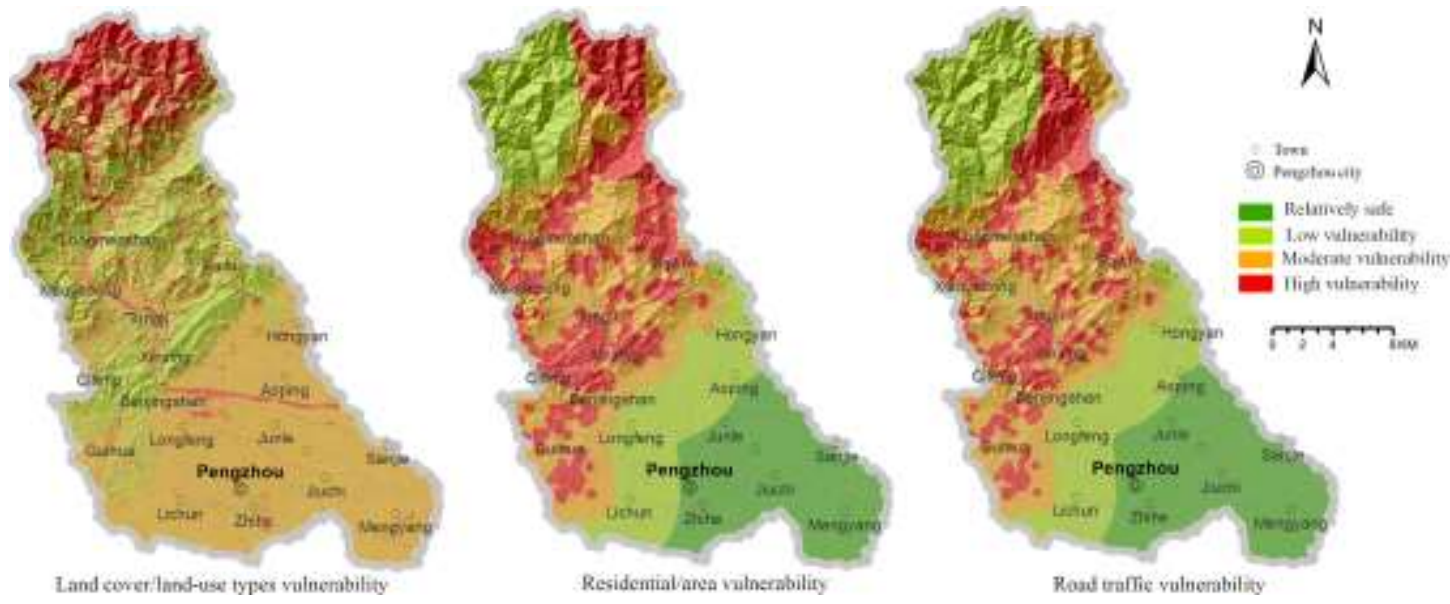

Figure 3. Hazard- Bearing Bodies Vulnerability and its Grading Distribution

Map

\subsection{Geological Disaster Risk Comprehensive Evaluation}

(1) Confirm the evaluation index weight. According to expert estimation, compare the relative importance degree between two of evaluation index respectively, the relative importance degree are defined as specific scale values, then establish judgment matrix, calculate the weight value (Table 2). Usually,-for judgment matrix of $m \geq 3$, when the CR $<0.1$, the consistency of judgment matrix is acceptable. After calculation the geologic disaster risk comprehensive evaluation judgment matrix, $\mathrm{CR}=0.0176$, so the consistency of judgment matrix is acceptable.

Table 2. Evaluation Index System and its Weight Value

\begin{tabular}{|c|c|c|c|c|}
\hline Target layer A & $\begin{array}{c}\text { Criteria layer } \\
\text { B }\end{array}$ & Weights & Index layer $\mathrm{C}$ & $\begin{array}{c}\text { Combination } \\
\text { weight }\end{array}$ \\
\hline \multirow{4}{*}{$\begin{array}{c}\text { Geological } \\
\text { disaster risk of } \\
\text { Longmenshan } \\
\text { fracture in } \\
\text { Peng zhou } A\end{array}$} & \multirow{4}{*}{$\begin{array}{l}\text { hazard } \\
\text { inducing } \\
\text { environment } \\
\text { factors } B_{1}\end{array}$} & \multirow{4}{*}{0.2174} & $\begin{array}{l}\text { Distance from the } \\
\text { fault } C_{11}\end{array}$ & 0.1204 \\
\hline & & & Sea-level elevation & 0.0156 \\
\hline & & & $\begin{array}{l}\text { Amplitude of } \\
\text { landforms } C_{13}\end{array}$ & 0.0526 \\
\hline & & & $\begin{array}{l}\text { Distance from the } \\
\text { river } C_{14}\end{array}$ & 0.0288 \\
\hline
\end{tabular}




\begin{tabular}{|c|c|c|c|}
\hline \multirow{4}{*}{$\begin{array}{c}\text { disaster- } \\
\text { causing factors } \\
B_{2}\end{array}$} & \multirow{4}{*}{0.4977} & $\begin{array}{l}\text { Seismic intensity and } \\
\text { distribution } C_{21}\end{array}$ & 0.2688 \\
\hline & & $\begin{array}{l}\text { Grading and } \\
\text { distribution of } \\
\text { aftershocks } C_{22}\end{array}$ & 0.1190 \\
\hline & & $\begin{array}{l}\text { Multi-year average } \\
\text { precipitation } C_{23}\end{array}$ & 0.0636 \\
\hline & & $\begin{array}{l}\text { Historical disaster's } \\
\text { scale and distribution } \\
C_{24}\end{array}$ & 0.0463 \\
\hline \multirow{3}{*}{$\begin{array}{c}\text { hazard bearing } \\
\text { bodies factors } \\
\mathrm{B}_{3}\end{array}$} & \multirow{3}{*}{0.2849} & $\begin{array}{l}\text { Land cover/land-use } \\
\text { types } C_{31}\end{array}$ & 0.0312 \\
\hline & & $\begin{array}{l}\text { Distance from } \\
\text { residential areas } \\
\text { distance } C_{32}\end{array}$ & 0.1657 \\
\hline & & $\begin{array}{l}\text { Distance from road } \\
\text { traffic } C_{33}\end{array}$ & 0.0880 \\
\hline
\end{tabular}

(2) Comprehensive risk scores and risk zoning. Set all risk assessment index as $30 \mathrm{~m} * 30 \mathrm{~m}$ raster data based on the CGCS2000 plane-coordinate system. In Raster Calculato of ARCGIS10.1, input the relative importance weight value of risk assessment index into space model, after calculation we obtained the geological disaster comprehensive risk scores distribution map Figure 4) . Based on the map, we divided geological disaster risk degree in Pengzhou into four grades; relatively safe, low risk degree, moderate risk degree and high risk degree by ARCGIS geometric interval classification, the geological disaster risk zoning of Pengzhou is accomplished, and the geological disaster risk zoning is mapped as below (Figure 5).

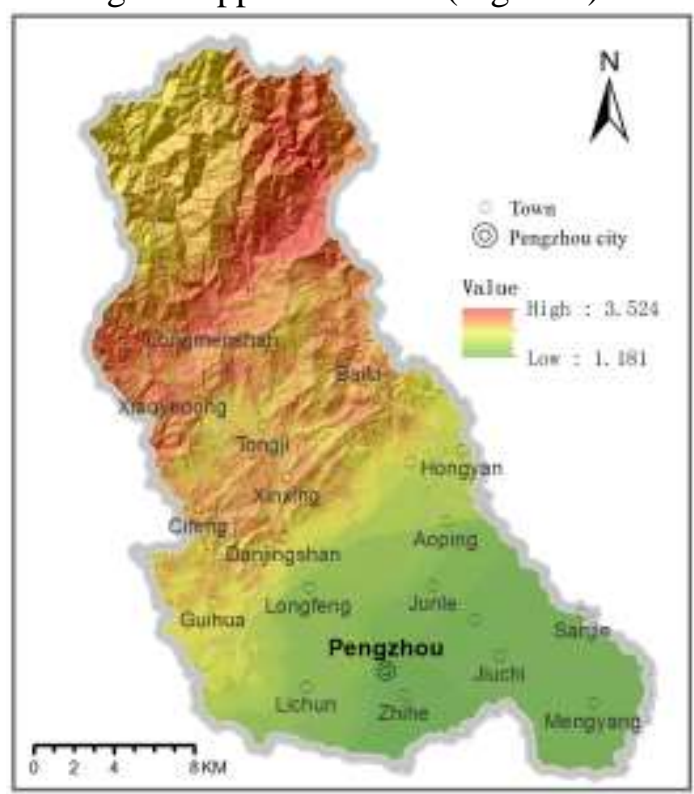

Figure 4. Geological Disasters Risk Comprehensive Score Distribution Map 


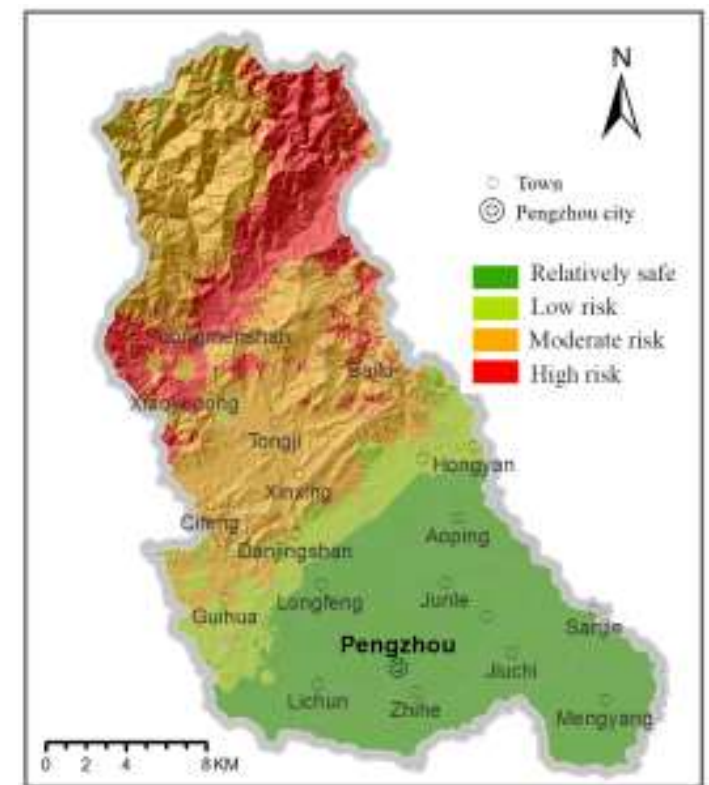

Figure 5. Geological Disasters Risk Zoning Map

According to the geological disaster risk zoning map of study area (Figure 5), and its area field, we got the statistical data of risk area, the results are shown in Table 3.

Table 3. The Statistic Table of Geological Disasters Risk Grading

\begin{tabular}{ccc}
\hline Risk level & Area $\left(\mathrm{km}^{2}\right)$ & Percentage $(\%)$ \\
\hline Relatively safe & 513.29 & 36.15 \\
Low risk & 158.73 & 11.18 \\
Moderate risk & 514.59 & 36.24 \\
High risk & 233.38 & 16.44 \\
Total & 1420.00 & 100.00 \\
\hline
\end{tabular}

\section{Conclusions and Discussions}

This article uses the GIS spatial analysis method and analytic hierarchy process (AHP), basing on the powerful functions of $3 \mathrm{~S}$ technology, spatial data collection and analysis to assess the geological disaster risk degree of Longmenshan fracture Peng zhou zone hazard inducing environment, as well as the disaster-causing factor, the hazard bearing bodies and other geological disasters risk factors. Then we got each index's weight through expert scoring method, then calculated the geological disaster risk degree comprehensive scores, and divided geological disaster risk degree in Pengzhou segment into relatively safe, low risk degree, moderate risk degree and high risk degree by ARCGIS geometric interval classification, the results showed that:

(1) We obtained the comprehensive scores of each index by AHP: hazard inducing environment factor, disaster-causing factor, hazard bearing body's weights were 0.2174 , $0.4977,0.2849$ respectively, the comprehensive evaluation judgment matrix $\mathrm{CR}=0.0176$, the consistency of judgment matrix is acceptable.

(2) High risk areas account for $16.44 \%$ of Pengzhou, and mainly distributed in northern mountainous region, such as Heifengdonggou、Guanzigou、Changheba、Xiaohaizi、 Yinchanggou in the Wudaohe river basin along Jian river upstream in Longmenshan town, Baishigou、Houbagou 、Hanxiagou、Hongshuigou river basin in Xiaoyugou town, Bailuhe in Bailu town and part areas in Cifeng town and Tongji town; moderate risk areas account for $36.24 \%$ of Pengzhou, and mainly distributed in northern 
mountainous region and central hilly areas, such as Huilonggou riverbasin and it's branch river in the northern mountainous region of Longmenshan town, Panjianghe、 Tuxihe river basin in Cifeng town, the major areas of Tongji town and Xinxing town, Tuxihe river basin of Guihua town, Yazihe river basin of Danjingshan town; low risk areas account for $36.15 \%$ of Pengzhou, and mainly distributed in central hilly areas, such as Hongyan distributing main canal、 Yazihe and Renminqu main canal river basin of Hongyan town, the distributing canal of Liudaoqu and Wudaoqu、Yanjiahe river basin of Gexianshan town, the distributing canal of Qingbaihe、 the diversion canal of Xihe reservoir and other river basin of Danjing town. Tuxihe、Chaobaijiang、Yinshuiquhe river basin of Guihua town. Qingbohe、puyanghe main canal、Gongjiayan branch canal and Qingbaijiang river basin of Lichun town. Relatively safe areas account for 36.15\% of the total area, mainly distributed in the eastern plain.

Geological disasters cause serious losses and threats to human society, and have serious impact on the sustainable development of social and economic, Comprehensive partition of geologic disaster risk degree can provide scientific basis for prevention and mitigation of geological disasters. Basing on present geological disasters risk zoning, while concentrating on the future, focusing on prevention, to establish and improve a sound disaster monitoring network and monitoring methods, use land resources rationally, and strengthen the training and education of geological disasters prevention. The research results closely matched the actual situation, but the selected evaluation index still exists certain gaps when comparing with the actual complicated factors because of the limited data, the scope of study area and the accuracy of data, the practicality of research results remain to be further tested.

\section{Acknowledgements}

This research was jointly funded by the project of National Natural Science Foundation of China (grant no. 41361091 and no. 41371486), and the open project of the ecological security and protection key laboratory of Sichuan province (grant no. ESP201304, QD2014A001), and the fund of Department of science and technology of Guizhou province ([2013]39, [2012]2279). We are grateful to the anonymous reviewers who made valuable and constructive comments on the manuscript.

\section{References}

[1] W. Zhe and Y. Facheng, "Geological hazards regionalization and research status quo in china", China Mining Magazine, vol. 15, no. 10, (2006), pp. 47-50.

[2] L. Kuo, Y. Jing and T. Chuan, "Risk assessment on geological hazards in Qingchuan Count of Sichuan Province", The Chinese Journal of Geological Hazard and Control, vol. 18, no. 2, (2007), pp. 54-57/121.

[3] Q. Yuan, L. Yong and Y. Zhenghua, "GIS-based analysis of landslide and debris flow hazard in Lanzhou", Journal of Glaciology and Geocryology, vol. 34, no. 1, (2012), pp. 96-104.

[4] A. Carrara, M. Cardinali, F. Guzzetti and P. Reichenbach, "GIS technology techniques in mapping landslide hazard", In: Carrara A, Guzzetti F(eds) Geographical information systems in assessing natural hazards, Kuwer Dordrecht”, The Netherlands, (1995), pp. 135-175.

[5] C. J. Van Westen, N. Rengers and M. T. J. Terlien, "prediction of the occurrence of slope instability phenomena through GIS-based hazard zonation, Geol Rundsch", vol. 86, (1997), pp. 404-414.

[6] S. Lee and K. Min, "Statistical analysis of landslide susceptibility at Yongin, Korea", Environmental Geology, vol. 40, (2001), pp. 1095-1113.

[7] L. Defang and D. Hui, "AHP-based on evaluation of occurrence easiness of geological disasters in Yongdeng Country”, Scientific \& Technical Information of Gansu, vol. 42, no. 12, (2013), pp. 10-13.

[8] B. Ruishou, "Geo-hazards risk assessment in the zone from Wudu to Hanwang along the Bailongjiang River", Lanzhou: Lanzhou University, (2014), pp. 1-20.

[9] G. Kechang, "The estimation of Wanzhou regional of landslide geo-hazards risk based on GIS analysis", Chongqing: Chongqing Normal University, (2003), pp. 40-45.

[10] Z. Bin, "The estimation of Wenchuan earthquake geo-hazards risk based on GIS", Beijing: Capital Normal University, (2011), pp. 51-60. 
[11] L. Xiaole, "Study on geological hazard risk assessment in the central region of Himalayan Mountains by the method of GIS", Changchun: Jilin University, (2012), pp. 1-10.

[12] Z. Xuefeng, "A case study of geological hazards risk assessment in a large scale mountainous environment", Chengdu: Chengdu University of Technology, (2011), pp. 1-22.

[13] N. Xi, Y. Dong and L. Ainong, "Mountain hazards risk zoning in the upper reaches of Mingjiang river", Journal of Catastrophology, vol. 30, no. 4, (2015), pp. 113-120.

[14] A. Forster, "The assessment of landslide hazard potential as a guide to land use and planning in the South Wales Coalfield", National Museum of Wales, vol. 24, (2005) November, pp. 81-87.

[15] R. M. Wooten, "Landslide hazards and landslide hazard mapping in North Carolina", Geological Society of America, vol. 38, no. 3, (2006) March, pp. 28.

[16] W. Shouqin, L. Renfeng and R. Qunzhi, "Application of GIS technology in the regionalization of geological hazards", Geology in China, vol. 32, no. 3, (2005), pp. 512-517.

[17] H. Yongshun, L. Chuan and C. Peng, "Susceptibility of mountain hazards triggered by Wenchuan earthquake to topographic factors", Journal of Sichuan University(Engineering Science Edition), S1, (2010), pp. 15-21.

[18] G. Yonggang, S. Guohu and G. Chaoxu, "Characteristics and cause of $8 \cdot 18$ debris flow hazards at the Longmenshan town, Pengzhou, Sichuan”, Journal of Hydraulic Engineering, no. (Z2), (2012), pp. 147154.

[19] L. Jingtao, W. Jun and W. Youming, "Research on development and distribution rules of geo-hazards induced by Wenchuan Ms8.0 earthquake", Journal of Catastrophology, vol. 30, no. 1, (2015), pp. 63-68.

[20] H. Shaou, "Monitoring and evaluation of dynamic vegetation change in Pengzhou city based on RS and GIS", Chengdu:Sichuan Normal Univercity, (2013), pp. 6-10.

[21] L. Yiqiu, L. Chunxia and D. Ou, "Biodiversity sensitivity zoning of river dam and reservoir engineering development", Acta Ecologica Sinica, vol. 34, no. 11, (2014), pp. 3081-3089.

[22] S. Xiaohua, "Research on the assessment of geological hazards based on GIS-a case study in Sichuan province", Beijing: Beijing University of Civil Engineering and Architecture, (2013), pp. 12-20.

[23] X. Xiqiong and H. Runqiu, "Risk assessment and risk management for slope geohazards", Journal of Geological Hazards and Environment Preservation, vol. 11, no. 1, (2000), pp. 38-41. 
International Journal of u- and e- Service, Science and Technology

Vol. 10, No. 1 (2017) 